\title{
Mainstreaming Environmental Finance into Financial Markets - Relevance, Potential and Obstacles
}

\author{
Peter Lindlein ${ }^{*}$
}

\begin{abstract}
Mainstreaming environmental finance widens the utilisation of existing instruments and extends them to environmentally beneficial activities. The objective is to serve clients in ways that make environmental finance a normal set of retail products. The sheer number of households and MSMEs (micro, small and medium enterprises) give providers the weight and opportunity to address environmental concerns. Financial institutions have a key role in environmental finance in ways that ensure sustainable development (Millennium Development Goal 7).

Households, MSMEs and municipalities have an enormous range of technically viable environmental investments. But the actual demand is still much below the potential. This is because the material and/or financial benefits of environmental activities have been limited. 'Greenbacks' have been more important than 'green thought'. However, this market is growing along with higher energy prices, and will grow further if the emphasis on subsidy is shifted from fossil energy to sustainable energy.

The current demand for environmental investment is limited. But many potential investments are on the frontier of viability. To increase their viability, they usually require longer maturities and a high sensitivity to the structure and the conditions of capital cost financing.

The trend of green financial products has not yet penetrated emerging markets and developing countries. Most banks are in the early stages of integrating environmental factors into their internal procedures, offering only a few financial products in this field, because they believe other opportunities earn higher returns. Environmental finance faces a three-dimensional gap between needs and supply: instruments, funds and conditions. These, and the insufficient knowledge, lack of institutional capacity, and opportunity and start-up costs, constitute the challenges for financial institutions entering the field of environmental finance. But success-
\end{abstract}

\footnotetext{
Chief Executive Officer, iCee GmbH.
} 
ful cases prove that there are significant advantages from approaches that at the same time address the demand for environmental finance and benefit both the financial institution and the borrower.

Increasing the range for such win-win situations will require substantial support from the international community, not only in the form of access to funds, but also in becoming more proactive by including environmental aspects in banks internal sustainability strategies. It will take enormous efforts for financial institutions and their international partners to capitalise on the fact that energy is money. Moreover, environmental protection means business - and money and business are bankable.

\section{The Relevance of Environmental Finance}

Environment - from renewable energy to resource efficiency, and from clean production to climate change: these concerns have risen to the top ranks of the global agenda of politics, business and finance. Massive problems predicted by some experts for decades are materializing. High fuel prices, shortages of electricity, massive environmental risks in emerging economies and man-made climate change have moved from the debating table to reality. After decades of controversial discussions these issues are emerging as facts, becoming mainstream topics of thought and policy. What was an opportunity has now become a necessity: the financial sector has to develop its approaches and instruments in order to make environmental finance a mainstream priority, responding to a challenge that is both local and global.

This is of special importance to developing countries and emerging economies. It seems obvious that their paths and patterns of growth cannot simply follow the stages of the industrialized countries. Both have to leap over into a stage of sustainable development. To 'Ensure Environmental Sustainability' is a Millennium Development Goal (MDG Target 7). Thus, environment is not something that is supplementary - it is an essential dimension of development, and environmental finance will have to be one of its crucial instruments.

There is a strong case for 'environmental finance', a term used for a wide range of activities and instruments at various levels. These have in common that the activities financed are supposed to contribute to the common good, which is 'environment'. From a financial sector perspective, this includes the direct financing of projects, (public) financial (dis-)incentive schemes, bilateral and multilateral projects and programmes, and global schemes such as carbon markets and global funds. 'Environmental finance' in reality is multidimensional, encompassing objectives, techniques, sponsors and regions, to name a few.

1 The increasing importance of environmental finance is underlined by the fact that 12 such funds were founded in 2007 alone, offering funds for various environmental activities and investment levels: Global Climate Change Alliance of the European Commission 
The following remarks refer only to simplified, stylized facts of that diverse universe, including providing basic energy to the poorest in least developed countries (LLDCs) in a sustainable way, improving building insulation in Eastern Europe, providing energy efficient and waste reducing equipment for micro, small and medium enterprises (MSMEs) in emerging markets, and building renewable energy plants for local supply everywhere. Furthermore, 'environment' may not even be the major purpose and benefit of such an activity, but only one important aspect. Therefore we must avoid tunnel vision, instead addressing a very wide range of activities, while exploring the relevance and potential of environmental finance through the financial sector.

Environmental finance through the financial sector? What does this term mean? It refers to any kind financial service (equity, credit, guarantees and insurance) on the demand side, consisting of producers, service companies, smaller municipalities and households for environmentally-relevant activities within the normal product line and client range of a financial institution. Mainstreaming environmental finance into the financial sector primarily means widening the use of existing institutions and instruments and extending them to the environmentallybeneficial activities of their existing and potential clients, making environmental finance a regular retail product. This may be done in combination with public incentive schemes and special funds.

Where does mainstream environmental finance fit in the spectrum of the financial sector? Toward one end is large-scale project finance, and toward the other is retail finance. From the clients' perspective, environmental finance probably resembles large-scale project finance. This would seem to be the case because households and MSMEs face major expenditures in the form of longterm investments, often with low annual costs but with returns and therefore benefits over long periods of time. But from the perspective of financial institutions these clients and their activities fall into another size category requiring an approach that is appropriate for a mass market of smaller activities. These consist of MSME finance and household finance, which may not always result in sufficient cash flow for income generation or cost reduction to cover debt service. For ecological, economic and social reasons, environmental finance cannot be restricted to large projects:

(GCCA), International Window of the Environmental Transformation Fund of the United Kingdom, German International Climate Initiative, German Life Web Initiative, Spanish-UNDP Spanish MDG Fund, NORAD Rainforest Initiative, Japanese Cool Earth Partnership, Australian Global Initiative on Forests and Climate, World Bank Forest Carbon Partnership Fund (FCPF), World Bank Clean Technology Fund (CTF), GEFIFC Earth Fund, World Bank Strategic Climate Fund (SCF) and Pilot Program for Climate Resilience (PPCR) and Kyoto Protocol Adaptation Fund. Source: Geer, Timothy (WWF International). The New Financing Architecture for the Environment - and some associated issues, Presentation in Manila, June 2008. 
- Along with renewable energy, energy and resource efficiency are topics for MSMEs as well as for households. Any approach that ignores the enormous possibilities for reducing energy consumption and greenhouse gas emissions of MSMEs and households would be incomplete. It would miss the potential to decouple economic development from the growth of energy consumption.

- Large renewable energy projects are very important due to their size and economies of scale. However, as millions of poor people have no direct access to the services and benefits of networks linked to these large projects, decentralised solutions are in order - and they require finance. Environmental finance through the financial sector can offer a shortcut to reach the poor, support decentralized solutions and directly improve the living conditions of the poor. For example, financial institutions can provide funds that can help the poor to use decentralized energy solutions, instead of waiting for years to be connected to the grid.

- Furthermore, the financial sector can channel funds to international and global schemes at the project level in the real sector, where change must occur. A strategic element could include important segments of the private sector as a step on the road to commercialisation and massification of environmental investment throughout the economy.

Working through the financial sector may also create strong impacts on the living conditions of the marginalised, making environmental finance an instrument of poverty alleviation. For example, this approach can contribute to opening up other energy resources for the poor in grids with limited electricity capacity.

Thus, both approaches - classic large-scale project finance and environmental finance through the financial sector - are complementary. Each contributes to the goals of environmental finance, making full use of practical solutions. Small projects and environmental finance through the financial sector can be simple and quick. Local financial institutions are close to the clientele: they know their track records and understand their concerns - and the possibilities to structure financial services accordingly.

The sheer number of households and MSMEs, their close relevance to environmental issues, and the opportunity to address their concerns directly give financial institutions a strategic role in environmental finance and in the massification required for sustainable development (MDG 7). Furthermore, without the inclusion of the target group of MSMEs and households, efforts to develop an open, rule-based, predictable and non-discriminatory financial system (MDG 8) would lack an essential pillar. Mainstreaming environmental finance into financial markets will improve income and living conditions. In poor countries this can help to a) reduce poverty (MDG 1); b) improve education (MDG 3) through improved school facilities and lighting at home; and c) improve health (MDG 4 and 6) through energy efficiency and infrastructure improvement through reduced pollution and better air quality. Clearly, financing investments and the corresponding development of the financial sector are closely relevant to both the achievement of the MDG goals and to harmonizing economic development with environmental sustainability. 
Engaging in environmental finance at the base of the economic and social pyramid could offer benefits for financial institutions:

- Financial institutions would engage in a burgeoning field that is becoming ever more important in both real and financial aspects. Thus, finance could secure its share of the growing 'green' market.

- Environmental finance can be good business, as can financial services that serve the poor. Like MSME finance, household finance and environmental finance offer an opportunity for business development, attracting new clients and strengthening relationships with present customers. This formula could strengthen the dynamics of the market.

- Financial institutions would find not only an opportunity for cross-selling and portfolio building. In addition, risk would be reduced as energy efficiency can improve clients' financial situations.

Clearly, there are benefits not only to individual financial institutions, but also to financial systems development. Mainstreaming environmental finance could extend the scope and size of the financial sector and deepen it by increasing the numbers of clients, providing better coverage, and offering newer products and longer maturities. Environmental finance could extend MSME promotion, offering this target group finance to strengthen their capacities in the fields of environment and energy, moving them a step further from survival towards sustainability.

To summarise, there is a substantial case for mainstreaming environmental finance into financial markets, but to a great extent environmental finance remains within the realm of potential. Why has this massive potential not been tapped further? One answer can be found in the real sector, which together with the financial sector, constitutes the economy. The next section, provides an overview of the demand for environmental financial products, after which the current state of the supply side and related challenges are presented.

\section{Overview of the Demand Side of Environmental Finance Markets}

A precondition for demand for environmental finance is an investment decision in the real sector, i.e. the demand for environmental products and equipment, which is the topic of the next sub-sections. Later, the way in which this real demand is transformed into demand for financial products will be closely examined.

\subsection{Types of Potential Investment Demand for Environmental Activities}

The typical potential clients of environmental finance include households, MSMEs in all sectors of the economy, and smaller municipalities. The following table gives an overview of their activities categorised by environmental areas: 
Table 1. Clients and Types of Environmental Activities

\begin{tabular}{|c|c|c|c|c|}
\hline $\begin{array}{l}\text { Clients/ } \\
\text { EF Type }\end{array}$ & Households & MSMES & Municipalities & Remark \\
\hline $\begin{array}{l}\text { Renewable } \\
\text { Energy }\end{array}$ & $\begin{array}{l}\text { Solar Water } \\
\text { Heating; } \\
\text { Solar- } \\
\text { Photovoltaic; } \\
\text { Biogas }\end{array}$ & $\begin{array}{l}\text { Biomass; } \\
\text { Small Hydro; } \\
\text { Wind; } \\
\text { Solar Water } \\
\text { Heating }\end{array}$ & $\begin{array}{l}\text { Small Hydro; } \\
\text { Biomass (waste } \\
\text { to energy); } \\
\text { Wind; } \\
\text { Solar PV }\end{array}$ & $\begin{array}{l}\mathrm{M}(\mathrm{SME}) / \text { munici- } \\
\text { palities power } \\
\text { suppliers in energy } \\
\text { generation } \mathrm{M}(\mathrm{SME}) \\
\text { and co-generation } \\
\text { (e.g. biomass) }\end{array}$ \\
\hline $\begin{array}{l}\text { Energy } \\
\text { Efficiency }\end{array}$ & $\begin{array}{l}\text { Lighting; } \\
\text { Domestic } \\
\text { Appliances; } \\
\text { Eco-efficient } \\
\text { Housing } \\
\text { (Retrofitting, } \\
\text { Insulation) }\end{array}$ & $\begin{array}{l}\text { Industrial } \\
\text { Energy } \\
\text { Efficiency; } \\
\text { Eco-efficient } \\
\text { Buildings }\end{array}$ & $\begin{array}{l}\text { EE Public } \\
\text { Lighting; } \\
\text { Public } \\
\text { Buildings; } \\
\text { Power } \\
\text { Distribution } \\
\text { Network }\end{array}$ & $\begin{array}{l}\text { Households, by } \\
\text { number almost all, } \\
\text { by amount mainly } \\
\text { the present better- } \\
\text { off consumers, i.e. } \\
\text { medium and high } \\
\text { income households; } \\
\text { Potential for loss } \\
\text { reduction through } \\
\text { improvement of } \\
\text { electricity } \\
\text { distribution network }\end{array}$ \\
\hline $\begin{array}{l}\text { Clean } \\
\text { Production }\end{array}$ & & $\begin{array}{l}\text { Resource } \\
\text { Efficiency incl. } \\
\text { Recycling; } \\
\text { End of Pipe } \\
\text { Approaches, } \\
\text { le.g., Sewage } \\
\text { Plants }\end{array}$ & & $\begin{array}{l}\text { Reduction of } \\
\text { Pollution and } \\
\text { Pollution Treatment }\end{array}$ \\
\hline $\begin{array}{l}\text { Climate } \\
\text { Insurance }\end{array}$ & & Small Farmers & & \\
\hline $\begin{array}{l}\text { Environ- } \\
\text { mental } \\
\text { Supply Chain }\end{array}$ & & $\begin{array}{l}\text { Equipment } \\
\text { Production; } \\
\text { Service } \\
\text { Companies }\end{array}$ & & $\begin{array}{l}\text { Local supply can be } \\
\text { a bottleneck; you } \\
\text { can import the } \\
\text { equipment, but the } \\
\text { service for } \\
\text { implementation and } \\
\text { maintenance may be } \\
\text { difficult to procure; } \\
\text { important to build } \\
\text { up production and } \\
\text { service capacities } \\
\text { and networks }\end{array}$ \\
\hline
\end{tabular}


This illustrates that there is an enormous range of investments in environmental finance which are technically and economically viable. The following figure gives examples of typical investment costs in relation to financial risk and classifies them into categories: ${ }^{2}$

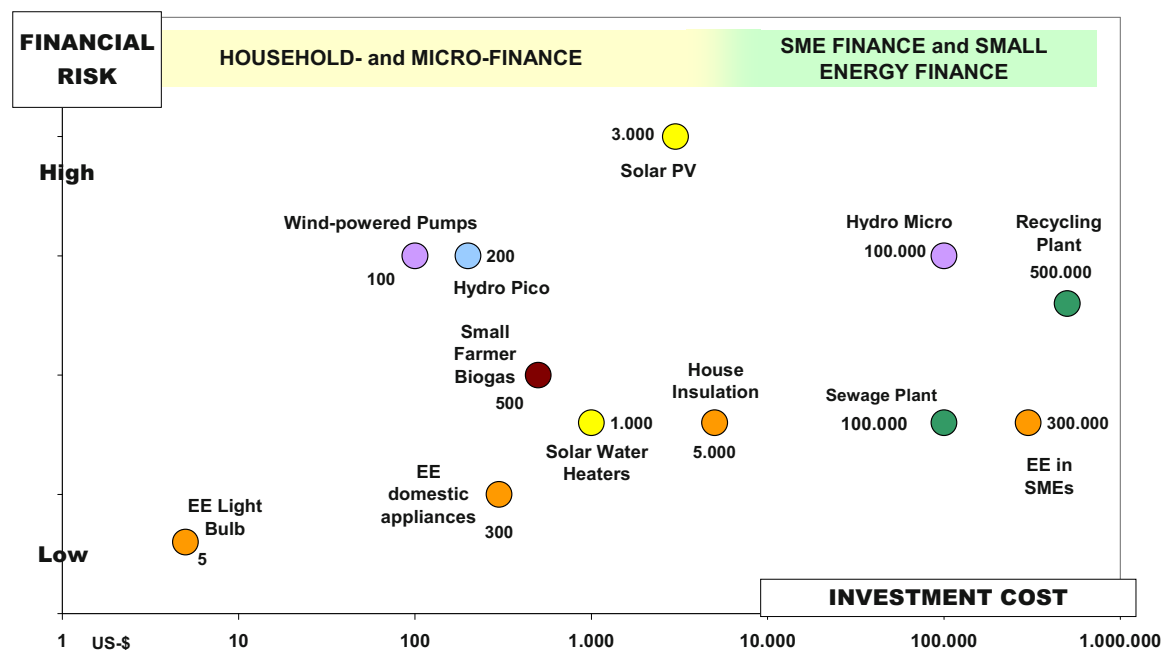

Fig. 1. Examples of Investment Cost and Financial Risk of EE and RE Investments

The figure includes activities having an investment cost of up to USD 1 million. The upper limit encompasses the great majority of loan amounts financial institutions in emerging markets and developing countries provide in their regular business with their clients. ${ }^{3}$

- For just a few dollars, households could improve energy efficiency by using compact fluorescent light bulbs for a few dollars; for a few hundred dollars, they could improve energy efficiency by employing modern domestic electrical appliances. Solar water heaters placed on roofs would cost a few hundred dollars and houses could be insulated for a few thousand. Improved public lighting would cost several hundred thousand dollars for smaller municipalities.

2 Adapted from: Lindlein, Peter and Wolfgang Mostert. Financing Renewable Energy. KfW Frankfurt, 2005.

3 However, in some emerging economies with larger banks and more advanced financial systems, projects with an investment cost of USD 5 million or more, such as smaller cogeneration plants, may be addressed by environmental finance through the financial sector; this closes the gap to typical structured project finance, which starts at about USD 10 million. 
- Renewable energy approaches range from USD 100 for Pico Hydro Units to over a few thousand dollars for Solar Photo-Voltaic Systems to USD 100,000 for Micro Hydro.

- Recycling plants and sewerage treatment, both with a very wide range of investment cost, are examples of resource efficiency and pollution abatement efforts by SMEs. Typical amounts for smaller units are several of a few hundred thousand dollars for smaller units.

The determination of what is actually economically and financially viable, and also expressed as demand, depends to a large extent on the framework conditions and energy prices in the respective country.

To grasp the size of the challenge, renewable energy projects alone are calculated by the IEA to be about USD 7 billion per year for all sizes of projects. This sum would enable renewable energy to comprise a significant portion of the energy consumption of developing countries. Donor assistance provides less than $20 \%$, leaving a huge financing gap. Market-based mechanisms are required to leverage much greater amounts, beyond what donors could supply.

\subsection{Reasons for Low Actual Investment Demand}

In general, the actual demand for environmental finance is far below the potential, despite the fact that the more advanced developing countries have often established their own policies for energy efficiency, renewable energies and pollution control. Some observers attribute this gap to a lack of awareness of and interest in the client target groups. They simply follow a "business as usual" rationale, which is similar for households and MSMEs:

- Poor people and small companies are first aware of a lack of access to goods and services, including modern energy forms and a lack of access to the grid. To engage these people, environmental activities must offer actual material benefits. Their rationale for engagement may take into consideration the environmental activities that affect them, but with little regard for the environmental effects of their own activities on the rest of society.

- Even if there are clear benefits, municipalities, MSMEs and households have limited funds to spend, and environmental activities are ranked low on the priority list. In their stressed situation, 'greenbacks' are much more important than 'green thought'. Financial institutions can provide funds to increase this limit, but clearly, there are limitations in the access to finance for both investors and for financial institutions.

- Another aspect is the time horizon. There is a strong preference for shortterm and intermediate returns. The long pay-back periods of energy efficiency or renewable energy are not sufficiently attractive. To be sustainable in the long run, this barrier has to be overcome. 
These rationales motivate decision makers to take different approaches to some of the main areas of environmental activities:

- Energy Efficiency: Here low demand is mainly a result of low and subsidized energy prices. Electricity prices in the range of USD 5-7 cts/KWh in countries such as Bolivia, Egypt, India and South Africa preclude material energy savings. The efficiency potential in households and in commerce is targeted only when a clear financial benefit is foreseeable. Rising electricity prices in Brazil, China and other countries will stimulate this demand.

- Renewable Energy: For most households and MSMEs, energy means access to the electricity grid. Individual household solutions are perceived as second best. They will never be connected to the grid controlled by the better off, causing an image problem for renewable energy solutions. In general, MSMEs have a more practical attitude in this matter and judge the potential solutions based on benefit and cost criteria. Commercial renewable energy approaches face a series of problems when linking to the grid is required, due to unfavourable framework conditions (i.e., regulations and prices). As renewable energy for a firm's own consumption does not face this bottleneck, investment in co-generation has flourished.

- Cleaner Production: In the case of pollution control and abatement in MSMEs, the common good benefits to the environment play a very minor role in determining individual decisions. Investment occurs only if environmental regulations are strictly enforced or a clear financial benefit is likely.

The present global change in energy prices and its local impacts make permanent energy subsidies impossible. The impacts of heavy pollution in urban areas that affect daily life are moving decision makers to alter their priority lists. Accordingly, thinking is starting to change and stronger action in all areas may follow.

However, many potential investors, especially households, are now facing a practical problem: the lack of systematic, solid, up-to-date information on the different technical and economic solutions and their availability and actual cost in a specific region. Although one may easily assume that the internet has improved the availability of data, many countries continue to lack reliable, practical information. This is related to the dearth of experience and data that might guide practical investment. In many countries, there are no showcases for environmental solutions within the reach of the decision-making public; uncertainty and high transaction costs hamper progress and experimentation. But when buying a solar water heater ( $\mathrm{SWH})$ is as simple as buying a car, as in China with its network of SWH-producers and suppliers, transaction costs decline and investment decisions are made by millions of consumers.

How can potential clients' awareness and propensity to invest be raised? The drivers behind the growth in 'green' financial products in Europe and the US are knowledge, awareness and regulation. People and companies in emerging markets and developing countries, each with different framework conditions, have differ- 
ent incentives and information. Their decision-making is not necessarily influenced by a common good but rather by individual benefits. Awareness campaigns should move beyond pleas for green consciousness. They should demonstrate potential individual benefits and practical ways of achieving them, offering reliable, clear, relevant and complete information. These goals can be promoted through case studies, the dissemination of practical knowledge and hands-on approaches. The solar service centres in Germany, for example, combine such strategies.

As the actual demand lies below the potential in these markets, so does the local production of the corresponding equipment and goods. Also, providers of installation and maintenance of environmental equipment are hard to find in many developing countries, especially outside the larger cities.

Giving clear information on the ways and benefits of environmental activities is easier said than done when prices are used to calculate the benefits. Market forces have limited predictability. In addition, the state and regulating bodies intervene in pricing through taxes, subsidies and regulations. Moreover, this is not always done in a reliable, predicable way that provides sufficient information for decisions regarding environmental activities which require a long-term perspective.

Combined, these factors contribute to high transaction costs and elevated risk and uncertainty for environmental actions in the perception of decision makers at all levels; this perception, in turn, inhibits decisions to allocate funds for environmental investment.

At present, the actual demand for environmental finance in emerging markets and developing countries is much lower than the potential, but there are already some sectoral and regional hotspots:

- Energy efficiency has already gained momentum in the industrial sector and in households; this is especially the case in Eastern Europe, which suffers from an outdated industrial base, poor housing conditions and large energy efficiency problems.

- Renewable energy creates significant demand as financial viability increases, as in the cases of wind and small hydro energy. Demand is also generated where considerable public support brings green solutions to the frontier of bankability, as in India and the Philippines.

- The present demand for cleaner production and pollution abatement is strong only when financial incentives (e.g., pollution fees) are instituted or when environmental standards, including the risk of disruption of operation, are legally enforced. ${ }^{4}$ Especially in reference to financial incentives and standards enforcement, "it is no coincidence that sustainability per-

4 An econometric study completed in 2000 in China (Wang, Hua. Endogenous enforcement and effectiveness of China's pollution levy system. Policy Research Working Paper WP 2336) shows that industrial plants respond strongly to pollution levies and enforcements either by abating pollution or end-of-pipe treatment for pollution. 
formance is linked to the political system", and that in some Latin American democracies this field is more active than in other regions.

Furthermore, there are strong drivers that increase demand. These include rising energy prices and pressing environmental problems, along with other aspects of globalisation. Trade agreements and growing environmental requirements from foreign buyers will force entrepreneurs in Asia to be more active as international investors, who will set environmental standards for their affiliates. Pressure from NGOs will grow as a result of their publicizing the consequences of environmental negligence and as technical solutions become more affordable.

\subsection{The Crucial Double Role of Subsidies}

Properly set, subsidies could create a cushion against the financial imperfections of the environmental investment market and help to create the personal incentives that are necessary for optimal investment decisions. ${ }^{6}$

However, despite liberalization of the energy sector in many countries, the prevailing framework conditions and subsidy schemes continue to expand environmental investment, which is to some extent the result of subsidized prices for fossil fuels. Global subsidies for energy (net of taxes) are estimated at USD 280 billion per year (about $0.6 \%$ of global gross domestic product), of which $94 \%$ are for fossil energy. ${ }^{7}$ Although the weighted average of consumer subsidies is rather low, consumers in some countries pay energy prices that are considerably lower than the average, especially for electricity: $20-40 \%$ lower, as depicted in Fig. 2. These are average rates; some consumers may enjoy even higher subsidies and lower tariffs.

Such state interventions are an element of social policy (e.g., India ${ }^{8}$ ) or they are intended to promote industrial investment (e.g., South Africa). But low energy prices are hardly an incentive to search for alternative generation or energy efficiency solutions. In fact, subsidies contribute to the low demand for environmental activities in these countries.

5 Jennifer Morgan, sustainable business manager at WWF-UK., In Mike Scott. Local conditions dictate the development of services. Financial Times, Sustainable Banking, Special Report, 3 June 2008.

6 For details see Session 2.

7 In most OECD countries, gross energy subsidies are heavily outweighed by taxes. But Russia and Iran have annual energy subsidies of about USD 40 billion, and six other countries - China, Saudi Arabia, India, Indonesia, Ukraine and Egypt - provide subsidies in excess of USD 10 billion per year each. All figures are net of taxes for each fuel source. Morgan, Trevor. Energy Subsidies: Their Magnitude, How they Affect Energy Investment and Greenhouse Gas Emissions, and Prospects for Reform. UNFCCC Secretariat/Financial and Technical Support Programme. June 2007.

8 See Stern, Nicolas. The Economics of Climate Change: The Stern Review. Report to the Cabinet Office, HM Treasury. Cambridge: Cambridge University Press, 2006, p.279. 


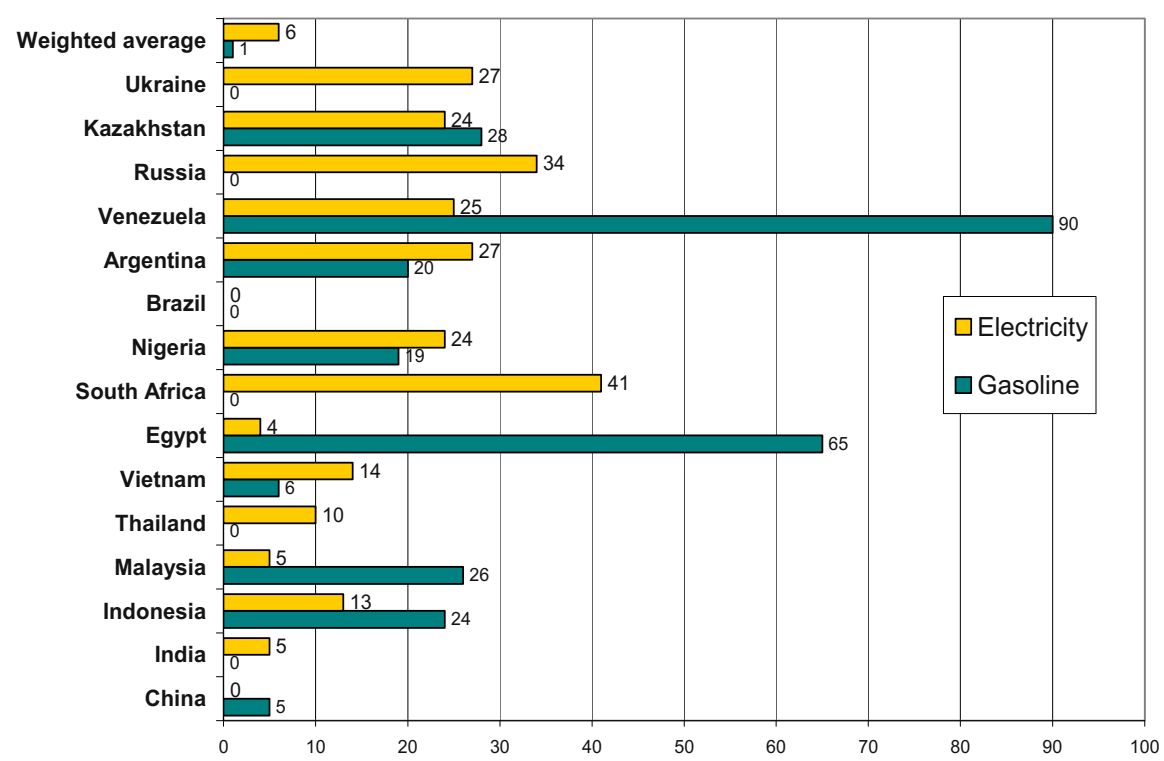

Fig. 2. Consumption subsidy as percentage of reference price in Non-OECD countries, 2005

Source: Morgan, Trevor. Energy Subsidies. 2007 based on figures from IEA.

With increasing real global prices for primary energy, the use of subsidies to keep prices at such low levels will at some point become unsustainable. Some countries listed in Figure 2 have already reacted and have increased energy prices substantially. Such actions will terminate a disincentive for environmental activities.

To reverse the subsidy balance in favour of sustainable energy and environmental solutions, and create an incentive for them, would help to secure the future instead of clinging to the past. But environmental subsidies are still rather limited: The Stern Report estimates that annual government support for deployment of renewable energy is currently on the order of USD 10 billion worldwide. ${ }^{9}$ However, many industrial countries and some developing nations have adopted subsidy incentive schemes to compensate for the higher costs of renewable energy investments. Different subsidy instruments are used, as the following examples illustrate:

- Germany had a scheme to promote renewable energy with higher feed-in tariffs to the grid and through the recovery of investment cost. This resulted in subsidies of about EUR $6 \mathrm{cts} / \mathrm{kwh}$ for the investors, which was more than twice the wholesale price at that time. This approach contributed substantially to the relative success of renewable energy, but at significant cost for all customers who had to finance the subsidy through a higher cost of electricity.

9 Figure without biofuels. See Stern, Nicolas. The Economics of Climate Change, p.367. 
- For some years China has halved the value added tax and income tax for wind and biogas.

- Ghana reduced the import tariff for compact fluorescent lamps (CFL) to replace incandescent lamps.

- Brazil had a successful scheme to promote its biofuel industry: farmers received subsidies to grow sugar-cane. The fuel price was also subsidised to make biofuel cheaper than petrol, and alcohol-powered cars had a lower VAT rate.

- India offers financing for renewable energy at favourable conditions through the Indian Renewable Energy Development Agency (IREDA).

In a proper context, targeted smart subsidies can enhance environmental investment. Lessons learnt suggest that they should address not only direct investment and operating costs, but should also include training and educational subsidies to build local expertise, user awareness, appropriate technology adaptation, quality standards and entrepreneurial activities. ${ }^{10}$ Smart subsidies build nascent markets without undermining incentives for clients or commercial firms. These subsidies should be based on the classic criteria for the design and evaluation of a subsidy, such as to reach a focus on the target group, achieve impact and output at the least cost subsidy and the means to finance it. In the case of environmental activities, this means: ${ }^{11}$

- A clearly defined target group is required; ideally this would be the decision makers for environmental activities.

- Subsidies should support least-cost options. The subsidy must be big enough to make a real difference for the decision maker, but subsidies are limited. Thus the targets for such subsidies should be the 'low-hanging fruits', i.e. renewable energy activities that are close to financial viability.

- Subsidies should encourage commercial participation by the private sector to leverage their impact.

- Subsidies should have a built-in phase-out date to maintain an incentive for producers to become financially viable.

All subsidies affect the bankability of environmental activities. Some do this through capital cost compensation schemes that lower the amount of subsidy; others affect bankability by increasing the returns of the activity. Of special importance for the financial sector are subsidies included within the financing terms. Such subsidies can take the form of lower interest rates or include risk-sharing and technical assistance at below market costs. The pricing of interest rate subsidies is ideally deter-

10 See Rijal, Kamal. Energy Subsidies in Developing Countries: Can we make it for those whom it is intended? Joint UNEP and UNECE Expert Meeting on Energy Subsidies, 2007.

11 Pros and cons on subsidies and details on the adequate approaches are discussed by Wolfgang Mostert in this volume. See also UNEP/IEA. Reforming Energy Subsidies, 2002. 
mined by the crucial line between the commercial market rate for average risks and the creation of adequate financial access for environmental activities, given the distortions in capital markets. Experience has proven that loans for special purposes with interest rates below the market rate are highly prone to misuse.

\subsection{Characteristics of the Demand for Environmental Finance}

Due to the relative amount of the cost and the limited funds available, the demand for environmental investment is almost automatically transformed into demand for environmental finance. The drivers of the diverse universe of environmental activities create a rather wide range of demand characteristics for environmental finance:

- Different client groups create demand for environmental finance; these range from poor households to MSMEs to small municipalities. The types of investment demanded range from improvement in personal living conditions to commercial activities to public investment. Motives include individual benefits in the form of improved living conditions, cost savings, long-term profitability and pollution abatement triggered by legal requirements. Medium-sized companies and municipalities may be motivated by social responsibility.

- Existing and new clients: Energy efficiency and cogeneration activities as well as pollution abatement investments are usually undertaken by companies/households offering a financial track record and a base for collateral. However, renewable energy projects often are greenfield activities initiated by new companies and developers.

- Partial cost base and different levels of cash-flow generation: The environmental aspect may be only one element of an investment activity, either being built-in (e.g. efficiency) or as one element of a major investment. Thus it may represent only part of the total cost, or it could come on top of other substantial costs. Not all the environmental activities create a direct cash flow.

- Type of finance and own funds: The type of finance they demand includes forms of mezzanine finance and risk instruments. The required loan amounts come in all sizes, often with limited own funds.

- Time horizon: The longer the payback period of the activity and/or the relation of investment cost to the disposable income, the longer are the maturities that are required.

Thus, demand for environmental finance arises from many different client segments of financial institutions, each requiring different financial products. Many of these activities are on the frontier of viability or bankability. What they have in common is a tendency to require longer maturities and a high sensitivity to the structure and the conditions of capital cost financing. This translates into a strong preference for interest rates in the lower range of the market. A classification of these demand characteristics is presented in the following table: 
Table 2. Characteristics of the Demand for Environmental Finance

\begin{tabular}{|c|c|c|c|c|}
\hline $\begin{array}{l}\text { Clients/ } \\
\text { Factor }\end{array}$ & Households & $\begin{array}{l}\text { Micro- } \\
\text { enterprises }\end{array}$ & SMEs & $\begin{array}{l}\text { Small } \\
\text { Municipalities }\end{array}$ \\
\hline $\begin{array}{l}\text { Kind of } \\
\text { activities }\end{array}$ & $\begin{array}{l}\text { - Renewable } \\
\text { Energy } \\
\text { - Energy } \\
\text { Efficiency }\end{array}$ & $\begin{array}{l}\text { - Renewable } \\
\text { Energy } \\
\text { - Energy \& } \\
\text { Resource } \\
\text { Efficiency } \\
\text { - Pollution } \\
\text { Abatement }\end{array}$ & $\begin{array}{l}\text { - Renewable } \\
\text { Energy } \\
\text { - Energy \& } \\
\text { Resource } \\
\text { Efficiency } \\
\text { - Pollution } \\
\text { Abatement } \\
\text { - Climate } \\
\text { Insurance } \\
\text { - Supply for } \\
\text { Energy and } \\
\text { Environment } \\
\text { Investment and } \\
\text { Operation }\end{array}$ & $\begin{array}{l}\text { - Renewable } \\
\text { Energy } \\
\text { - Energy } \\
\text { Efficiency } \\
\text { - Pollution } \\
\text { Abatement }\end{array}$ \\
\hline Motivation & $\begin{array}{l}\text { - Personal } \\
\text { Benefit }\end{array}$ & $\begin{array}{l}\text { - Personal/ } \\
\text { Commercial } \\
\text { Benefit }\end{array}$ & $\begin{array}{l}\text { - Commercial } \\
\text { Benefit } \\
\text { - Legal } \\
\text { Requirement } \\
\text { - (Corporate } \\
\text { Social } \\
\text { Responsibility) }\end{array}$ & $\begin{array}{l}\text { - } \text { Budget } \\
\text { - Social } \\
\text { Responsibility } \\
\text { - Legal } \\
\text { Requirement }\end{array}$ \\
\hline $\begin{array}{l}\text { Types of } \\
\text { financial } \\
\text { products }\end{array}$ & $\begin{array}{l}\text { - Loans } \\
\text { - Insurance }\end{array}$ & $\begin{array}{l}\text { - Loans } \\
\text { - Insurance } \\
\text { - Guarantees }\end{array}$ & $\begin{array}{l}\text { - Equity } \\
\text { - Loans } \\
\text { - Leasing } \\
\text { - Guarantees } \\
\text { - Insurance }\end{array}$ & $\begin{array}{l}\text { - Loans } \\
\text { - Guarantees } \\
\text { - Insurance }\end{array}$ \\
\hline $\begin{array}{l}\text { Amounts } \\
\text { (Loans) in } \\
\text { USD }\end{array}$ & $10-10,000$ & $100-100,000$ & $\begin{array}{l}100,000- \\
1,000,000\end{array}$ & $1,000,000+$ \\
\hline $\begin{array}{l}\text { Maturities } \\
\text { (Loans) }\end{array}$ & Medium - Long & Medium - Long & Long & Long \\
\hline $\begin{array}{l}\text { Collateral } \\
\text { Base }\end{array}$ & $\begin{array}{l}\text { - Personal } \\
\text { Property }\end{array}$ & $\begin{array}{l}\text { - Property } \\
\text { - Cash Flow }\end{array}$ & $\begin{array}{l}\text { - Property } \\
\text { - Cash Flow }\end{array}$ & $\begin{array}{l}\text { - Budget } \\
\text { - Cash Flow }\end{array}$ \\
\hline
\end{tabular}

How and to what extent this demand could be met by the supply of the financial sector is explored in the next section. 


\section{Overview of the Supply Side of Environmental Finance Markets}

\subsection{Markets, Actors and Products}

Analysis of the mainstreaming of environmental finance into regular product lines has to consider two aspects: the development of normal business practice and the approach and practice of environmental finance.

The revolution of financial markets and the progress many financial institutions have made in the last decade(s) are impressive. But despite globalisation, the scope of products offered by commercial financial institutions varies enormously, depending on the maturity, outreach and the degree of a country's financial sector development. Limited access to common financial instruments and products constrains the demand for environmental finance. Mainstreaming environmental finance has to consider the condition and shortcomings of this sector and its institutions, as the table below illustrates. ${ }^{12}$

Table 3. Typology of Commercial Financial Markets

\begin{tabular}{|l|l|l|l|l|}
\hline $\begin{array}{l}\text { Classification of } \\
\text { Markancial }\end{array}$ & $\begin{array}{l}\text { Availability of } \\
\text { Financing } \\
\text { Instruments }\end{array}$ & $\begin{array}{l}\text { Availability of } \\
\text { Risk-Mitigation } \\
\text { Instruments }\end{array}$ & $\begin{array}{l}\text { Typical } \\
\text { Constraints }\end{array}$ & Examples \\
\hline $\begin{array}{l}\text { Advanced } \\
\text { Emerging } \\
\text { Financial } \\
\text { Markets }\end{array}$ & Advanced & Limited & $\begin{array}{l}\text { Limited access } \\
\text { to mezzanine } \\
\text { finance }\end{array}$ & $\begin{array}{l}\text { India, Thailand, } \\
\text { Philippines, } \\
\text { Mexico, South } \\
\text { Africa, China }\end{array}$ \\
\hline $\begin{array}{l}\text { Emerging } \\
\text { Financial } \\
\text { Markets }\end{array}$ & Regular & None- minimal & $\begin{array}{l}\text { Limited access } \\
\text { to long-term } \\
\text { finance; equity, } \\
\text { leasing and risk } \\
\text { instruments } \\
\text { difficult to } \\
\text { access }\end{array}$ & $\begin{array}{l}\text { Former CIS, } \\
\text { Argentina }\end{array}$ \\
\hline $\begin{array}{l}\text { Basic Financial } \\
\text { Systems }\end{array}$ & Very Basic & None & $\begin{array}{l}\text { Very limited } \\
\text { product range; } \\
\text { only short- and } \\
\text { mid-term loans }\end{array}$ & $\begin{array}{l}\text { Mopgolia, } \\
\text { Nepal }\end{array}$ \\
\hline
\end{tabular}

12 For a detailed country ranking of the maturity of financial markets see The Financial Development Report 2008 by the World Economic Forum, especially Pillar 7: Capital availability and access, p.13. 
In some emerging markets and many developing countries there is still a gap in the supply of mainstream products. In some cases, MSMEs and poor households have no access at all to formal financial institutions. These countries may also lack the base upon which environmental finance for this target group could be offered.

The acceptance that financial institutions offer towards environment and sustainability is a process marked by several stages of development: ${ }^{13}$

- Defensive banking: Non-active, delaying or opposing environmental aspects as criteria, because they are perceived to undermine business with good clients not interested in green finance, to produce insufficient contributions to profitability goals, and/or to increase the overall risk exposure of the bank, as environmental finance has to compete with traditional products.

- Reactive banking: Inclusion of environmental aspects in internal activities; reduction of credit risk by integrating environmental issues in credit risk assessment processes.

- Competitive sustainability advantage: Proactive, full integration of the external side, offering environmentally-friendly finance, continuously looking for win-win solutions.

- Responsible competitiveness: The bank does not look for the highest shortterm financial rate of return, but for the highest sustainable rate of return, while being profitable in the long run. This means that the bank finances environmental projects at somewhat higher risk, lower rates of return and longer payback periods in comparison to standard short-term funding, in order to strengthen its strategic position based on a long-term perspective.

Interest in sustainability varies according to local characteristics. The actual progress that financial institutions make in these stages of integration of environmental aspects into policy and action differs by region and the maturity of the financial sector:

- In Asia, many banks perceive the environmental legal risk of their clients as rather low, and they are not very active in this field. They pay much more attention to renewable energy finance, which is strongly supported by governments and offers attractive opportunities for banks. ${ }^{14}$

- In Eastern Europe, banks' attitudes mirror the approach of society: there are firm regulations, but weak enforcement. Equally important for potential

13 See for example: Jeucken, MHA and JJ Bouma. The Changing Environment of Banks; African Institute of Corporate Citizenship (AICC) - Sustainability Banking in Africa, Johannesburg, 2004.

14 IFC. Banking on Sustainability. Financing Environmental and Social Opportunities in Emerging Markets, Washington 2007, Chapter 1. 
borrowers is the fact that the large banks tend to be linked to large financial industrial groups or to powerful regional governments and concentrate their lending on group members. Thus there are some isolated examples of nearcommercial loans in the environmental sectors. ${ }^{15}$ Energy-efficiency is gaining attention.

- In Latin America - despite having award-winning banks in this field many financial institutions still have to integrate environmental dimensions into their internal systems. The attitudes of such banks have been described as a central bottleneck for environmental activities. ${ }^{16}$

- In Africa the financial services sector has responded far more slowly to the challenges and opportunities that environment presents. Private sector financial institutions are particularly behind in this respect. The African banking sector's understanding of environmental risk is limited and there is little recognition of the potential offered. ${ }^{17}$

This does not mean that the bigger banks in emerging markets do not have environmental finance products on their list. ${ }^{18}$ But the massive trend of green financial products and services found in Europe, where dozens of banks offer products like green mortgages, ${ }^{19}$ clean car loans, climate credit cards or eco-deposits, has not yet penetrated emerging markets and developing countries. Most of the banks in emerging markets are in the early stages of integrating environmental aspects into their internal procedures and offer only a few financial services and products in this field.

Thus in many developing countries there are no products tailored for or targeted to environmental finance, which is still in its early stages of complex and lengthy case-by-case financing. The only option for households and MSMEs is to use the banks' customary financial products, which are designed for other purposes and therefore do not have appropriate conditions for environmental activi-

15 OECD. Financing Water and Environment Infrastructure. The Case of Eastern Europe, the Caucasus and Central Asia, OECD 2006, p.70ff.

16 See the evaluation of clean production financing programs: Pratt, Lawrence and others. Analisis de Mecanismos para el Financiamiento de la Produccion mas Limpia en la Pequeña y Mediana Empresa Latinoamericana. FOMIN/BID, July 2003.

17 African Institute of Corporate Citizenship (AICC). Sustainability Banking in Africa. Johannesburg 2004, p.15ff.

$1838 \%$ of respondents of a survey of 26 financial institutions in 14 Central and Eastern European (CEE) countries provide at least one environmental financial product. Source: UNEPFI. Finance \& Sustainability in Central \& Eastern Europe. 2004.

19 E.g. for green mortgages: if the buildings meet higher energy efficiency standards, it is assumed that future energy costs are lower, thus leaving a higher disposable income for debt service. This increase in debt-service capacity could be used either to increase the loan amount or to reduce the risk premium. 
ties. This means that regular household loans would be used to finance solar-water heater or housing energy efficiency measures, which would be carried out on an ad hoc basis due to the limited funds and terms available.

However, this gap in commercial financial markets is not completely shut. The gap is narrowed by non-commercial financial institutions, consisting of parastatal development banks and special institutions, (green) microfinance institutions and NGOs. They offer financial products which are relevant or even targeted for environmental finance. Non-banking financial companies, like the Indian Renewable Energy Development Agency (IREDA), offers terms up to 15 years, and many microfinance institutions have become established parts of the financial market. The special institutions offer medium- to long-term loans for selected environmental purposes, such as specific renewable energy technologies. Green microfinance institutions provide financial services to the poor for the acquisition of sustainable small energy solutions like wind pumps. However, their products and outreach appear rather limited.

Environmental activities may imply special risks, such as renewable energy that has a fuel risk. Risk instruments are needed to reduce such risks for the project sponsor and the financial institutions. Renewable energy may depend on wind and rainfall; small farmers who are affected directly by climate change may benefit from weather insurance. However, the commercial insurance market is in its early stages in many developing countries. These countries are unable to cope with this challenge without support. International insurance companies such as the Allianz Group are trying to extend their outreach to renewable energy. However they are hampered by a lack of creditworthy local insurers, restrictive local insurance regulations and limited distribution channels. ${ }^{20}$

A lack of data is one of the biggest problems facing local insurance industries in developing countries today. This has implications for environmental investment in these countries, because operating histories are difficult to model accurately, in turn making it difficult to project future loss and price risk in an economic and sustainable manner. Linked to this issue are the low insured values associated with small scale projects, which make it difficult for underwriters to achieve an underwriting profit even on loss-free accounts. However, promising pilot schemes such as those of ICICI Lombard in India have sold weather insurance to more than 250,000 farmers across India. ${ }^{21}$ Institutions such as Opportunity International Bank of Malawi (OIBM) and the Malawi Rural Finance Corporation (MRFC), with significant start-up support from donors, are now offering packaged loan and indexbased microinsurance products to groups of farmers.

20 Marsh Ltd. Survey of Insurance Availability for Renewable Energy Projects. March 2006.

21 ICICI Lombard offers weather insurance for mustard crops; Source: Moneycontrol.com, Published on 1 September 2008. 
International structures like the carbon market are important sources of environmental finance. Impressive developments include more than 3,000 projects in 68 countries that were targeted to reduce 2,500 million tons of carbon dioxide equivalent to a market volume exceeding USD 60 billion in 2007. Another positive development is the emergence of secondary markets trading financial products, such as monetisation of future carbon receivables and carbon delivery guarantees. $^{22}$ However, these schemes are complex, burdened with very lengthy, costly procedures with an unpredictable result. The project design document has to be approved by government at the national level, then validated by a Designated Operation Entity before it can be approved by the CDM Executive Board and registered. The cost for this process is estimated at USD 100,000, which makes it clear that smaller environmental activities can benefit only when they are bundled. This bundling approach is also necessary for medium-sized projects, as investors indicate that without these CDM funds their approval cannot be assured. Thus contrary to politicians' intentions, carbon credits take the character of a cherry on top of a cake. Nevertheless, the financial sectors in emerging markets are responding to these schemes, and some international banks are trying to promote CDM markets in the poorest countries. ${ }^{23}$

\subsection{Problems in the Supply of Finance for Environmental Activities}

The green wave in financial services in Europe and the US is a rather recent phenomenon. For many years the popular perception was that banking is relatively neutral in regard to environmental aspects. The influence that its clients exercise over natural resources was not considered. So it is not surprising that in emerging markets and developing countries, neither corporate environmental responsibility nor opportunities for environmental finance have received the consideration they deserve. Despite some progress, the problems listed in a survey of Latin American banks several years ago seem to characterise many financial institutions: ${ }^{24}$

- "The majority of managers in Latin America are still not taking environmental risk into consideration in their credit screening processes. Efforts are limited to checking legislation and environmental assessment in project financing, but not in mainstream loans to companies."

22 State and Trends of the Carbon Market 2008.

23 Banco Sumitomo Mitsui Brasileiro in Brazil increased its portfolio of carbon credits in 2007 by 1.5 million credits, generated from 15 small- and medium-sized projects, including biomass power generation, small hydro projects and methane technology. One of the bank's innovations has been to set up a payment bond issuance to guarantee the payments to be made by Japanese companies buying credits. Standard Bank currently has five projects in Africa. Source: Hartley, Fiona: Benefits of trading trickling southwards, in: Financial Times - Sustainable Banking, Special Report, 3 June 2008.

24 Pacheco Capella, Alberto. Sustainable Finance: An assessment of environmental risks and opportunities in Latin America. Lund 2002. 
- "A vast majority of managers are not aware of the opportunities of the 'green' market, due to a lack of information."

- "Legislation governing banking and the environment is either lax or nonexistent. Legislation and stakeholders are necessary to create a sustainable shift in banking in the region."

The lack of awareness and attention explains why understanding and sectoral knowledge remain limited in financial institutions. This includes the extent to which environmental activities mean good banking business. This implies that risks may be overestimated while the benefits of these activities are underestimated. However, it is not easy to build the required expertise because financial institutions in these countries face the same information problems in evaluating risks as do their clients. In this situation environmental finance is considered unattractive because the perceived risk is not adequately covered by appropriate instruments or higher returns.

This leads to possibly the most important cause of the low supply of environmental finance, which is easily forgotten in the discussion of pure environmental finance: financial institutions in developing countries seem to have sufficient alternative opportunities to earn higher returns at lower risks than with other products and clients. So even if environmental finance means business, it is not attractive enough to be put on the priority list, mirroring the situation on the demand side. However, this situation changes completely when the environmental component is linked to cross-selling high return products. Examples include household loans with an energy efficiency element, a housing loan with an additional amount for an energy-efficient housing component, company loans for modernisation or extension including an additional amount to meet a pollution regulation.

There is still a lack of priority for pure environmental finance. This should not be surprising given the experience in Europe and the US, where green financial products have responded to trends in society and in the real economy, which were seen as efforts to expand mature financial markets. But even there, green financial products have fallen short of industry expectations. ${ }^{25}$ The real challenge in this area is not simply the introduction of new niche 'green' labelled products, but rather the integration of environmental incentives into mainstream commerce. This leads to the main challenge and problem: what has really flourished in the Western world is the financing of environmental activities which are financially attractive to both the borrower and the financial institution. This is mainly due to conducive framework conditions and incentive schemes, creating a triple win for the investor, the financier and for society.

25 UNEPFI. Green Financial Products and Services. August 2007. 
Despite all the promising and successful examples of environmental finance in emerging markets, ${ }^{26}$ the mainstream financial sector in developing countries is characterized in this respect by a three-dimensional gap in environmental finance between the needs and the supply:

- Available financial instruments, especially for the larger activities in the segment, which require some risk instruments, and for financial instruments linked to the supply of technical solutions like leasing.

- Amount of funds: Environmental activities are often afterthoughts to the common financial concerns of households and MSMEs. Adding the environmental dimension requires additional funds, exhausting debtors' credit limits assigned by financial institutions. Furthermore, these additional amounts and/or the new financial products require additional refinance, which may be a problem for the financial institution.

- Term structure may be an even more important consideration. A number of environmental investments require medium or long-term maturities. Financial institutions may be reluctant to provide longer maturities. Many banks still have a serious maturity mismatch between mid- to long-term lending requirements, and they suffer a shortage of access to corresponding refinancing.

\section{Challenges for Financial Institutions}

Where the price signals given either by the market or the state are strong, environmental initiatives flourish, and advanced financial markets responded to this demand. Globalization is developing rapidly with mergers in the financial sector, which will deepen markets, open refinancing channels and increase lending capacity. Especially in the case of environmental finance, global banks may standardize their policies across their international networks.

Market forces in the real sectors and increases in energy prices will be two additional strong drivers that will increase the demand for environmental activities, especially for energy efficiency. Financial institutions will not wait for ideal framework conditions, but rather will start to analyze current bankable demand and do their homework in order to increase their business in this field.

According to an IFC study, the global potential for lending to energy efficiency projects alone is USD 80 billion per year. ${ }^{27}$ The huge demand of environmental investment will require financing, giving financial institutions a fundamental role

26 To cite individual examples would be arbitrary, but a look at the awards and shortlists of the Financial Times Sustainability Banking Awards in recent years offers valuable insight.

27 Banking on Sustainability. Financing Environmental and Social Opportunities in Emerging Markets. Washington 2007, p.60. 
in sustainable development. In Europe and the US, state-of-the-art engagement practices by commercial banks respond to this challenge along two main tracks:

- By addressing the environmental credit risk of borrowers, banks improve their risk management and express their social responsibility. They signal that industries should improve environmental management practices. They identify opportunities for investment and finance with their clients. In this respect they may deal with environmental problem cases and turn them around into new business.

- 'Environmental finance' is focusing on greater investments in environmentally sound companies, environmental investments, infrastructure and clean energy. $^{28}$

Thus, financial institutions have to deal strategically and comprehensively with the risk elements and the opportunities of environmental finance.

To move from defensive banking to proactive banking, financial institutions must overcome internal challenges. A recent study identified the following barriers to financing in environmental activities: ${ }^{29}$

- Insufficient knowledge: It is hard to get relevant and reliable information about the opportunities and benefits of investing in these areas of business in emerging markets. But the lack of knowledge also reflects the fact that many banks have not undertaken systematic initiatives in this field.

- Lack of institutional capacity: Scarce generic information, limited practical experience, and lack of training contribute to the failure of many loan officers' inability to assess potential investment opportunities that include innovative environmental applications. This is a special challenge in rural areas.

- Matching financial conditions: Longer payback periods require longer loan terms. This may severely limit financing possibilities, because many financial institutions in developing countries do not have adequate access to long-term refinancing and have a limited capacity for term transformation.

- Opportunity costs due to lower returns: Many of these environmental activities are relatively small in size and have high transaction costs, like financing of SWH. Others cannot generate a direct financial benefit at all, although they are necessary for the client. These include pollution abatement for commercial enterprises, so that they can continue in business under new regulations, which may strain their debt service capacity. For the lending

28 Emtairah, Tareq; Hansson, Lars; Hao, Guo. Environmental challenges and opportunities for banks in China: the case of the Industrial and Commercial Bank of China, in Greener Management International. March 2007.

29 IFC. Banking on Sustainability. Financing Environmental and Social Opportunities in Emerging Markets, Washington 2007, p.56. 
institution, the returns generated from such transactions are smaller than those of other, less risky ventures, demonstrating that there is opportunity cost in environmental finance.

- Set-up cost: Integrating environmental concerns into a financial institution and developing environmental products require substantial resources.

It is simple to claim that "these issues can be resolved by gaining access to financial resources and technical assistance from the international development community and investors." ${ }^{30}$ Despite all the sectoral barriers there are opportunities, especially in agro-business, energy efficiency and renewable energy. Ecotourism has also been discovered by banks that have participated in workshops on sustainable finance. ${ }^{31}$

There are clearly lessons from successful cases. These include Banco Real (Brazil), Nedbank (South Africa) and Industrial Development Bank of Turkey (TSKB). ${ }^{32}$ However, each institution must develop its own approach and make its own commitment: $:^{33}$

- The first step is to be aware of the requirements and potential of environmental business. These must be identified and assessed systematically under prevailing market conditions and in consideration of the drivers which will change them soon. Financial institutions should undertake market research and analyses of the environmentally-related requirements and preferences of various customer segments. It is important to identify and focus on the win-win situations that reduce opportunity cost over time. This approach results in a sustainable and operational strategy.

- The next step is to implement the required changes, starting by highlighting the implications for corporate governance and integrating environmental risk into the portfolio and its management. Comprehensive integration requires hiring, supporting and training specialised managers or consultants, and allocating resources to develop a knowledge management framework.

30 IFC. Banking on Sustainability. Financing Environmental and Social Opportunities in Emerging Markets, Washington 2007, p.56.

31 Annex: Research Methodology and Survey Results to Banking on Sustainability. Financing Environmental and Social Opportunities in Emerging Markets, Washington 2007.

32 See the winners of the Regional Sustainable Banking Awards of the IFC and the Financial Times in recent years.

33 See the IFC Study, and also the 'Practitioner's Ideas for Innovation Tomorrow' (p.67) and the 'Paths to Sustainability Banking' (p.75) in African Institute of Corporate Citizenship (AICC). Sustainability Banking in Africa, Johannesburg 2004 and UNEP Finance Initiative. Green Financial Products and Services - Current Trends and Future Opportunities in North America. 
- Then clients and partners should be identified by a) communicating these changes externally, starting with existing clients; b) participating in thematic trade fairs and arranging workshops for branches of industry; c) networking and forming alliances, cooperating with suppliers and dealers of environmental equipment and services, and learning from successful examples which are now becoming more numerous in emerging financial markets, as in the cases of Banco Real in Brazil and the Industrial and Commercial Bank in China; and d) through the identification of publicprivate-partnerships.

- Adjust/expand the line of financial products in scope and depth, possibly in cooperation with other financial sector institutions, e.g. to find long-term refinance, adequate guarantees and insurance. Financial institutions should attempt to understand and design green products in the same way that conventional banking products are treated. This is particularly important when considering key product-enhancing features, such as flexibility, userfriendliness and ease of personnel management.

- Financial institutions can attempt to overcome perception barriers and stimulate demand for green products and services through creative, educational marketing campaigns.

- The institutions must devise systems to monitor and verify all of these aspects.

Steps to address the challenges of environmental finance should go beyond the mere risk aspects within the different areas of a bank. These steps are listed in Table 4.

There are substantial potential benefits for banks to use these tools and incentives, as confirmed by a recent survey of 120 financial institutions in 43 countries: $^{34}$

- Include environmental aspects in loan assessments, risk management and financing products. These procedures diversify and strengthen the portfolio and help indirectly to reduce the risk of non-performing loans $(74 \%$ of the respondents).

- Work to enter a market with a huge growth potential that will attract new clients $(35 \%)$ and increase business with existing clients through crossselling with environmental financial products. These strategies can foster revenue growth $(9 \%)$.

- With these types of activities, early entrants in particular can enjoy higher visibility in the market, contributing to increased business and brand value $(39 \%)$.

34 IFC. Banking on Sustainability. Financing Environmental and Social Opportunities in Emerging Markets. Washington, 2007, p.12ff. 
Table 4. Internal Bank Activities that can Mainstream Environmental Finance

\begin{tabular}{|c|c|}
\hline Internal Resources & Activity and Value Added \\
\hline Human Resources & $\begin{array}{l}\text { - Provide skills training to account officers that focuses on sus- } \\
\text { tainability as a marketing tool to win business from priority mar- } \\
\text { ket segments } \\
\text { - Provide incentives and rewards for staff that achieve triple bot- } \\
\text { tom line investments (financially, socially and environmentally } \\
\text { high performing) } \\
\text { - Use the institution's sustainability track record to recruit high } \\
\text { calibre business school graduates }\end{array}$ \\
\hline Risk/Credit Review & $\begin{array}{l}\text { - Carry out environmental and social risk assessments of invest- } \\
\text { ments } \\
\text { - Assist loan officers in the differential risk pricing of loans }\end{array}$ \\
\hline Syndicates & $\begin{array}{l}\text { - Secure lead management of syndicates for complex projects } \\
\text { - Bring additional co-financing to complex sectors; participation } \\
\text { by additional banks may rely on the sound environmental and } \\
\text { social due diligence of the lead institution }\end{array}$ \\
\hline $\begin{array}{l}\text { Marketing and } \\
\text { Corporate } \\
\text { Relations }\end{array}$ & $\begin{array}{l}\text { - Work with account officers and priority clients to identify needs } \\
\text { as a basis for client sustainability } \\
\text { - Develop marketing materials and communications tools to ap- } \\
\text { proach target markets } \\
\text { - Develop communications tools to mainstream sustainability in- } \\
\text { ternally } \\
\text { - Manage SRI communications and develop communications ma- } \\
\text { terials in approaching additional non-clients and stakeholders } \\
\text { (NGOs, raters, analysts, etc.) }\end{array}$ \\
\hline $\begin{array}{l}\text { Retail Relationship } \\
\text { Manager }\end{array}$ & $\begin{array}{l}\text { - Identify smaller-cap client base with sustainability needs } \\
\text { - Lead sector-wide marketing to the client base (e.g. seminars on } \\
\text { process efficiency or on identifying export market opportunities } \\
\text { for sustainable companies) }\end{array}$ \\
\hline Treasury & $\begin{array}{l}\text { - Issue green payables (e.g., earmarked green deposits; eco-bonds) } \\
\text { based on the institution's sustainable portfolio } \\
\text { - Secure access to international funds }\end{array}$ \\
\hline $\begin{array}{l}\text { Environment and } \\
\text { Sustainability }\end{array}$ & $\begin{array}{l}\text { - Provide strategic overviews } \\
\text { - Provide central environmental and social advisory functions }\end{array}$ \\
\hline
\end{tabular}

Source: Extracted from IFC. Beyond Risk, table 'Mainstreaming sustainability', p.54. 
Thus, there is a long catalogue of tasks to meet the challenges. Many smaller and medium-sized financial institutions may need substantial support to adapt. This is similar to the situation of microfinance more than a decade ago, which has proved that many bankable activities can create new markets. These new markets can be exploited with the proper financial techniques and support, although matching longer maturities - a very important aspect of environmental finance - still may require external support.

\section{Perspectives and the Role of Donor Support in Environmental Finance}

With increasing environmental problems, demand for environmental investment will rise. There are already signs of a new boom in green investment in the industrial countries. And reality also bites in the emerging economies: the recent blackouts in South Africa and massive environmental problems in the emerging economies make it clear that the demand for environmental finance will increase globally and locally. The global rush for energy and resources will include renewable energy and affect searches for environmental solutions such as resource efficiency. More renewable energy technologies, such as photovoltaic technology, will move towards commercial viability. This will happen at all levels and project sizes. The financial sectors in emerging markets and developing countries will have to make efforts to cope with this demand. Financial institutions will have to acquire new capacities and extend their financial capabilities.

Cooperation at an international level will be crucial. Donors and global (semi-) commercial funds will be required, as they can provide the capital for environmental finance at matching maturities. Donors' objectives and instruments should include support for access to commercial finance by making equity and long-term debt finance available in sufficient quantities and on competitive terms for investments in EF projects. Priority activities and instruments should focus on the gaps in the financial sector in the countries concerned. This may include: ${ }^{35}$

- Supporting the private industrial sector, including MSMEs, equipment producers, vendors, service companies, by providing enterprise development support, seed capital, debt finance, mezzanine finance (e.g., Central American Renewable Energy and Cleaner Production Facility/CAREC) and equity (e.g., IFC Renewable Energy and Energy Efficiency Fund/REEF; ADB Clean Energy Private Equity Investment Fund; KfW environmental credit lines for BMI Apex Bank in El Salvador, and for ProCredit Bank Ukraine);

35 For details on lessons of these and similar projects, factors of success and future approaches, see the chapter in this publication by John MacLean. 
- Supporting the Specialized Financial Institutions for RE, microfinance and funds (e.g. KfW credit lines for the India Renewable Energy Development Agency/IREDA), energy efficiency (Bulgaria Energy Efficiency Fund) and microfinance (Grameen Shakti in Bangladesh financing household solar PVs and biogas systems);

- Creating new financial vehicles such as revolving funds, credit lines and contingent business loans;

- Reducing (commercial) risks through financial guarantees (such as IFC Guarantee Facilities for Energy Efficiency e.g. "Gas fired heating for households" by Raiffeisen Leasing in Hungary with a loss reserve guarantee) and insurance schemes (such as the Global Index Reinsurance Facility/GIRIF supported by IFC and KfW).

Most of these approaches are not new. Donors and DFIs have used such schemes in many cases. Where inferior results were achieved, neither the market and framework conditions nor the financial institutions were fully prepared to cope at that time. Although there have been many successful programmes designed and implemented by certain financial institutions, their structural impact on the financial sector often has been limited. However, with adequate framework conditions, commercial financial institutions have learned from the experiences of successfully promoted financial institutions. These include IREDA in India, where domestic banks such as IDBI, ICICI and IFCI among others, subsequently developed their own environmental finance business.

Market conditions for environmental activities are changing on a global scale, as is the willingness of banks to cooperate and work systematically in this endeavor. At the beginning this may seem to be a difficult task, because it affects their ongoing business and may hamper the operation of otherwise easy business with good clients. It is not by chance that $86 \%$ of the financial institutions participating in the abovementioned IFC survey expressed an interest in receiving further technical assistance in this field. This includes staff training, access to industrial risk briefings, and practical tools such as software for environmental assessment.

On the sectoral level, donors could support countries in obtaining access to the various (semi-) commercial international environmental funding sources. The dialogue with governments should address framework conditions (energy tariffs and taxes, market regulations) and offer support for their adjustment. To be convincing, this will require more than just good arguments. Although the budget priority lists are changing, this (financial) challenge imposes an additional burden for the developing countries. Additional funds will be required to guide the adjustment process and cushion the social blow. Dialogue with banks should focus on a transfer of hands-on experience that stresses that environmental finance can indeed be good business. 


\section{Conclusions}

The global market is growing with higher energy prices. There is increasing awareness of the priorities for environmental investment on one side. There is also a large set of technical solutions offered by a growing specialized environmental industry. The main fuel of industrialisation - oil - may run dry during our lifetimes, and has already become much more expensive. This will make many renewable energy and energy efficiency activities financially viable and increase the demand for finance.

There is an opportunity and a priority for mainstreaming environmental finance. The cooperation of the financial sector is essential for this approach. It should offer the target group adequate finance to meet its needs in environment and energy, and to directly improve their living conditions so that they can face their challenges and make the step from survival to sustainability. But such environmental activities will occur only if there is a clear financial benefit for both the financial institution and the borrower. Increasing the range for such win-win situations will require substantial support from the international community for the financial sector. This support has to be not only in the form of access to adequate funds; in addition, support is required to help financial institutions overcome their defensive attitudes and become more proactive. This requires financial institutions to include environmental aspects in their own sustainability strategies. It will take enormous efforts for them and their international partners to capitalise on the fact that energy is money and environmental protection means business - and money and business are bankable.

\section{References}

African Institute of Corporate Citizenship (AICC) (2004) Sustainability Banking in Africa. Johannesburg.

Corporation of London and DEFRA: Financing the Future. The London Principles. The Role of UK Financial Services in Sustainable Development. London.

Emtairah, T., Hansson, L., Hao, G. (2007) Environmental Challenges and Opportunities for Banks in China: The Case of Industrial and Commercial Bank of China. In: Greener Management International, March 2007.

Financial Times (2008) Sustainable Banking. Special Report, 3 June 2008.

International Energy Agency (IEA) (2008) World Energy Outlook 2008. Paris.

International Finance Corporation (IFC) (2004) Beyond Risk, Sustainability and the Emerging Markets Financial Sector. Washington.

IFC (2007) Banking on Sustainability. Financing Environmental and Social Opportunities in Emerging Markets. Washington. 
Jeucken, M.H.A., Bouma, J.J. (2001) The Changing Environment of Banks. In: The 2001 Symposium of the International Research Network for Quality, Environment and Corporate Social Responsibility, 22 June 2001 Nijmegen. Shipley: ERP Environment.

Lindlein, P., Mostert, W. (2005) Financing Renewable Energy. Frankfurt: KfW.

MARSH Ltd. (2006) Survey of Insurance Availability for Renewable Energy Projects. UNEP, March 2006.

OECD (2006) Financing Water and Environment Infrastructure. The Case of Eastern Europe, the Caucasus and Central Asia. OECD.

Pacheco Capella, A. (2002) Sustainable Finance: An Assessment of Environmental Risks and Opportunities in Latin America. Lund.

Pearce, B. (2002) Financing the Future: The London Principles of Sustainable Finance.

Pratt, L., Rojas, E. (2001) Programa ambiental en bancos latinoamericanos: Una Evaluacion, Centro Latinoamericano de Competitividad. INCAE Costa Rica.

Pratt, L. et al. (2003) Analisis de Mecanismos para el Financiamiento de la Produccion mas Limpia en la Pequeña y Mediana Empresa Latinoamericana. FOMIN/BID, July 2003.

Rijal, K. (2007) Energy Subsidies in Developing Countries: Can We Make It for Those Whom It Is Intended? Joint UNEP and UNECE Expert Meeting on Energy Subsidies.

Schmidheiny, S., Zorraquín, F. (1996) Financing Change: The Financial Community, Eco-efficiency and Sustainable Development.

Stern, N. (2006) The Economics of Climate Change: The Stern Review. Report to the Cabinet Office, HM Treasury. Cambridge: Cambridge University Press.

Taylor, R.P. (2008) Financing Energy Efficiency: Lessons from Brazil, China, India, and Beyond. Washington: World Bank.

UNEP/IEA (2002) Reforming Energy Subsidies.

UNEPFI (2004) Finance and Sustainability in Central and Eastern Europe.

UNEP Finance Initiative (2007) Green Financial Products and Services - Current Trends and Future Opportunities in North America. A Report of the North American Task Force (NATF) of the United Nations Environment Programme Finance Initiative. August 2007.

World Economic Forum (2008) The Financial Development Report. Geneva.

Open Access. This chapter is distributed under the terms of the Creative Commons Attribution Noncommercial License, which permits any noncommercial use, distribution, and reproduction in any medium, provided the original author(s) and source are credited. 